\title{
Improving the Quality of Life of Persons with Disabilities by Promoting Their Professional Rehabilitation
}

\author{
Victoriia Overchuk ${ }^{1}$, Julia Kushnir ${ }^{1}$, Oksana Shportun ${ }^{2}$, Lyudmila Matokhniuk ${ }^{3}$, Zhanna Sydorenko ${ }^{4}$, \\ Kateryna Vasyuk $^{5}$, Viktoriya Shevchuk ${ }^{6}$, Ihor Bloshchynskyi ${ }^{7, *}$ \\ ${ }^{1}$ Department of Psychology, Donetsk National University named after Vasily Stus, Vinnytsia, Ukraine \\ ${ }^{2}$ Department of Psychology, Public higher educational establishment «Vinnytsia academy of continuing education», Ukraine \\ ${ }^{3}$ Doctor of Psychological Sciences, Professor, Head of the Department of Psychology Public higher educational establishment \\ «Vinnytsia academy of continuing education», Vinnytsia, Ukraine \\ ${ }^{4}$ Department of Psychology, Donetsk National University named after Vasily Stus, Vinnytsia, Ukraine \\ ${ }^{5}$ Department of Psychology, Donetsk National University named after Vasily Stus, Vinnytsia, Ukraine \\ ${ }^{6}$ Department of General and Engineering disciplines, Bohdan Khmelnytskyi National Academy of the State Border Guard Service of \\ Ukraine, Khmelnytskyi, Ukraine \\ ${ }^{7}$ Department of Foreign Languages, Bohdan Khmelnytskyi National Academy of the State Border Guard Service of Ukraine, \\ Khmelnytskyi, Ukraine
}

Received April 13, 2021; Revised June 8, 2021; Accepted June 20, 2021

\section{Cite This Paper in the following Citation Styles}

(a): [1] Victoriia Overchuk, Julia Kushnir, Oksana Shportun, Lyudmila Matokhniuk, Zhanna Sydorenko, Kateryna Vasyuk, Viktoriya Shevchuk, Ihor Bloshchynskyi, "Improving the Quality of Life of Persons with Disabilities by Promoting Their Professional Rehabilitation," Universal Journal of Public Health, Vol. 9, No. 3, pp. 140 - 148, 2021. DOI: 10.13189/ujph.2021.090305.

(b): Victoriia Overchuk, Julia Kushnir, Oksana Shportun, Lyudmila Matokhniuk, Zhanna Sydorenko, Kateryna Vasyuk, Viktoriya Shevchuk, Ihor Bloshchynskyi (2021). Improving the Quality of Life of Persons with Disabilities by Promoting Their Professional Rehabilitation. Universal Journal of Public Health, 9(3), 140 - 148. DOI: 10.13189/ujph.2021.090305.

Copyright $(2021$ by authors, all rights reserved. Authors agree that this article remains permanently open access under the terms of the Creative Commons Attribution License 4.0 International License

\begin{abstract}
The article considers fundamental aspects of ensuring the quality of life of persons with disabilities in Ukraine, recognition of their rights to a full life in society and the creation by the state of appropriate conditions for their rehabilitation and social integration. There have been significant changes in attitudes towards people with disabilities in recent decades. The basis of such changes is the recognition of their rights to a full life in society and the creation of appropriate conditions for their rehabilitation and social integration, but, despite the positive changes, the quality of life of people with disabilities lags far behind and does not meet today's requirements. Today in Ukraine, the employment of people with disabilities is part of vocational rehabilitation, the purpose of which is to provide them with work directly. The article is devoted to the study of the development and supports system of vocational training of persons with disabilities in Ukraine. Particular attention is paid to the structure of state and non-state institutions,
\end{abstract}

through which vocational training of persons with disabilities is carried out. The critical shortcomings of the vocational education system of persons with disabilities in Ukraine are selected. In particular, in terms of financing such education, logistics for certain groups of persons with disabilities, as well as educational institutions and enterprises that need to adapt their place of study or work to the needs of persons with disabilities. The feasible analysis also indicates the shortcomings of the Procedure for choosing a profession for people with disabilities with the participation of medical and social expert commission (MSEC). Recommendations for overcoming these shortcomings are formulated separately.

Keywords Professional Orientation, A Person with a Disability, Employment, Integration, Socialization, Models of Disability 


\section{Introduction}

One of the essential factors in the progressive development of society is the humane, compassionate and caring attitude towards people who are deprived of the opportunity to have a full life due to defects in physical and mental development. Disability is a social phenomenon that no society can avoid. There have been significant changes in attitudes towards people with disabilities in recent decades. The basis of such changes is the recognition of their rights to a full life in society and the creation of appropriate conditions for their rehabilitation and social integration. Still, despite the positive changes, the quality of life of people with disabilities lags far behind and does not meet today's requirements.

Some researches revealed Ukrainian polar explorers' psychological readiness for extreme environments of the "Academician Vernadsky" Antarctic station. They specified the concept of psychological readiness for extreme environmental conditions, determined the age limits of the studied groups, presented methodological tools of psychological research. The three aspects of readiness of the polar explorers, namely psychophysiological, personality, social-psychological have differentiated. (Miroshnychenko, Pasichnyk, Voznyuk, Kubitskyi, Roganova, Tsvietkova, Shorobura, Bloshchynskyi, 2020). People with disabilities need special attention from society, and conditions must be created for them to feel equal among equals. After all, the attitude to this category of people determines the degree of state's civilization so that people with disabilities could find work, start a family, get an education, vocational training, organize leisure and recreation, improve their social level, they need to integrate into society by interacting with various social institutions successfully.

Quality of life is a concept that is defined as how people perceive health as a result of functional limitations that affect their professional and social life (Khayatzadeh-Mahani, Wittevrongel, Nicholas, Zwicker, 2020). The quality of life is a complex characteristic of satisfaction the material and cultural needs of people, the prevailing living conditions, the free development of the individual and society as a whole. This feature includes the existence of comfort and security, stability of habitat and housing, welfare, access to education and culture, efficiency sphere of health care, etc.

Also, limiting the daily activities of people with disabilities hurts their socialization. The physical, psychosocial and economic levels of people with disabilities affect the quality of life, and there is a relationship in which the degree of socialization of a person with a disability is inversely proportional to the quality of life (Gokcen, Gonca, 2017).

Some scholars considered whether children's age and the time of adoption affect the development of personality, regarding the attachment relationship between children and parents in Hungary. They mapped how the personality of adopted children changes after getting to a family, and what the characteristics of its development are. According to their research the possibility of adoption came up in most of the families included in the study after medical interventions and the acceptance of infertility (Rucska, Perge (2020).

Other researchers assessed and described the knowledge, attitudes and practices of patients diagnosed with tuberculosis related to their treatments in Keetmanshoop district in Karas region, Namibia. They concluded in the study that the respondents had a good knowledge on tuberculosis with regards to signs and symptoms of the disease but there was poor knowledge and misperceptions existed on the risk factors associated with transmission of tuberculosis such as shaking hands and drinking from the same cup with others (Kateta, Villiers, Iita, 2020).

The basis of the social protection principle of people with disabilities is not social security as a passive function of social protection, but their protection through the creation of appropriate conditions for them in society and equal opportunities for the realization of life needs, abilities, creativity. If a person loses health to some extent, he needs more attention from others and society in general. Such citizens need to be involved in social activities, in work to the best of their strength and abilities, that they will be full and active members of society. Solving the problem of a low level of involvement of persons with disabilities in public life allows to ensure their complete socialization, including the development of social skills, obtaining the necessary knowledge for full functioning in society, and as a result greater self-confidence and higher competitiveness in the labour market.

\section{Materials and Methods}

\subsection{Methodology of Research}

The methodological basis of our research were general scientific and unique methods of socio-economic research. During the writing of the article, the practices of theoretical generalization, abstraction, analysis and synthesis were used to study the development of basic concepts and scientific approaches, system analysis; to clarify the features of the rehabilitation system and employment of persons with disabilities in Ukraine.

The need for changes in social policy regarding the rehabilitation and employment of persons with disabilities became especially relevant after the audit of the implementation results in Ukraine of the provisions of the UN Convention on the Rights of Persons with Disabilities. The obtained conclusions emphasize the existence of 
unresolved issues, in particular, in the field of rehabilitation and employment of persons with disabilities. This situation has led to active discussions and increased interest of scientists in various areas in the implementation of social policy in ensuring the rehabilitation and employment of persons with disabilities in the current conditions of the labour market. An essential role in understanding the evolution of scientific views on the problems of the labour market, industrial relations, wages, rehabilitation and employment of disadvantaged groups play an essential role such scientific works.

Without diminishing the importance of the scientific and practical contribution of the above scientists, scholars, practitioners, it should be noted that the degree of unresolved issues in the field of rehabilitation and employment of persons with disabilities in Ukraine, as well as the pace of change in socio-economic life, necessitate the deepening of further research in this area

\subsection{The Main Presentation of the Material}

According to the World Health Organization, about 15\% of the world's population has a disability. Some researchers even claim that this is a low estimate, given the different ways of defining disability in various countries (Vornholt et al, 2018). Concerning employment and participation in the labour market, people with disabilities are unemployed group workforce (Colella, Bruyère, 2011). In Ukraine, the unemployment rate of people with disabilities significantly exceeds the unemployment rate among the normative population, although most of them want and can work.

Besides, high unemployment among people with disabilities coexists with a deficit in various sectors of the labour market; especially it concerns many European countries due to demographic changes and reduced fertility. According to this, today, some European countries mark a significant decrease in the working-age population (Vornholt et al, 2018). Besides, most industrialized countries face an ageing workforce, which makes the level of disability due to chronic diseases among workers more pronounced (Truxillo, Fraccaroli, 2013). With the ageing of the workforce, the fight against disability will become even more critical in the future. Demographic change is affecting about a third of Europe's regions in terms of declining competitiveness. The extent to which these developments will affect economic growth depends considerably on labour participation (Vornholt et al, 2018). Due to the expected decline in the working-age population, especially in European countries, people with disabilities are increasingly recognized as a valuable resource of labour in both the private and public sectors.

\section{Results}

Today in Ukraine, the employment of people with disabilities is part of vocational rehabilitation, the purpose of which is to provide them with work directly. The work of employment services in the employment direction of persons with disabilities begins with a careful analysis of each situation based on an individual rehabilitation programme (IRP). According to the Regulations on the personal rehabilitation programme for a person with a disability, IRP is a set of optimal types, forms, amounts, terms of rehabilitation measures with the order determination, place of their implementation, aimed at restoring and compensating for impaired or lost body functions and abilities of a person with disabilities and a child with a disability (The Cabinet of Ministers of Ukraine, 2007).

The IRP is developed with the participation of a person with a disability within one month from the date of such person's application to medical and social expert commission (MSEC). According to the order of the Ministry of Health of Ukraine "On approval of forms of an individual rehabilitation programme for persons with disabilities, a child with disabilities and the Procedure for their preparation"( Ministry of Health of Ukraine, 2007), the form includes a list of life restrictions that a person may have. This restriction is to:

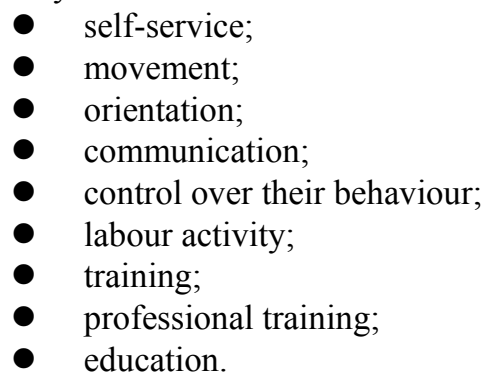

The degree of restriction is measured on a three-level scale and includes limitations of I, II and III degrees. In this case, a person with a disability may have only one restriction, whereas by other criteria, she will not differ from a person without a disability. This information on the degree of disability, illness and limitations is the basis for the formulation of recommendations for rehabilitation measures and their implementation, which also include vocational and occupational rehabilitation.

As part of vocational rehabilitation, MSEC has to:

- examine potential professional abilities;

- conduct professional orientation;

- provide recommendations for professional selection;

- guide professional training, retraining and advanced training;

- teach vocational education.

In a simplified form, the decision-making algorithm for choosing the profession of a person with a disability is shown in Figure 1. 


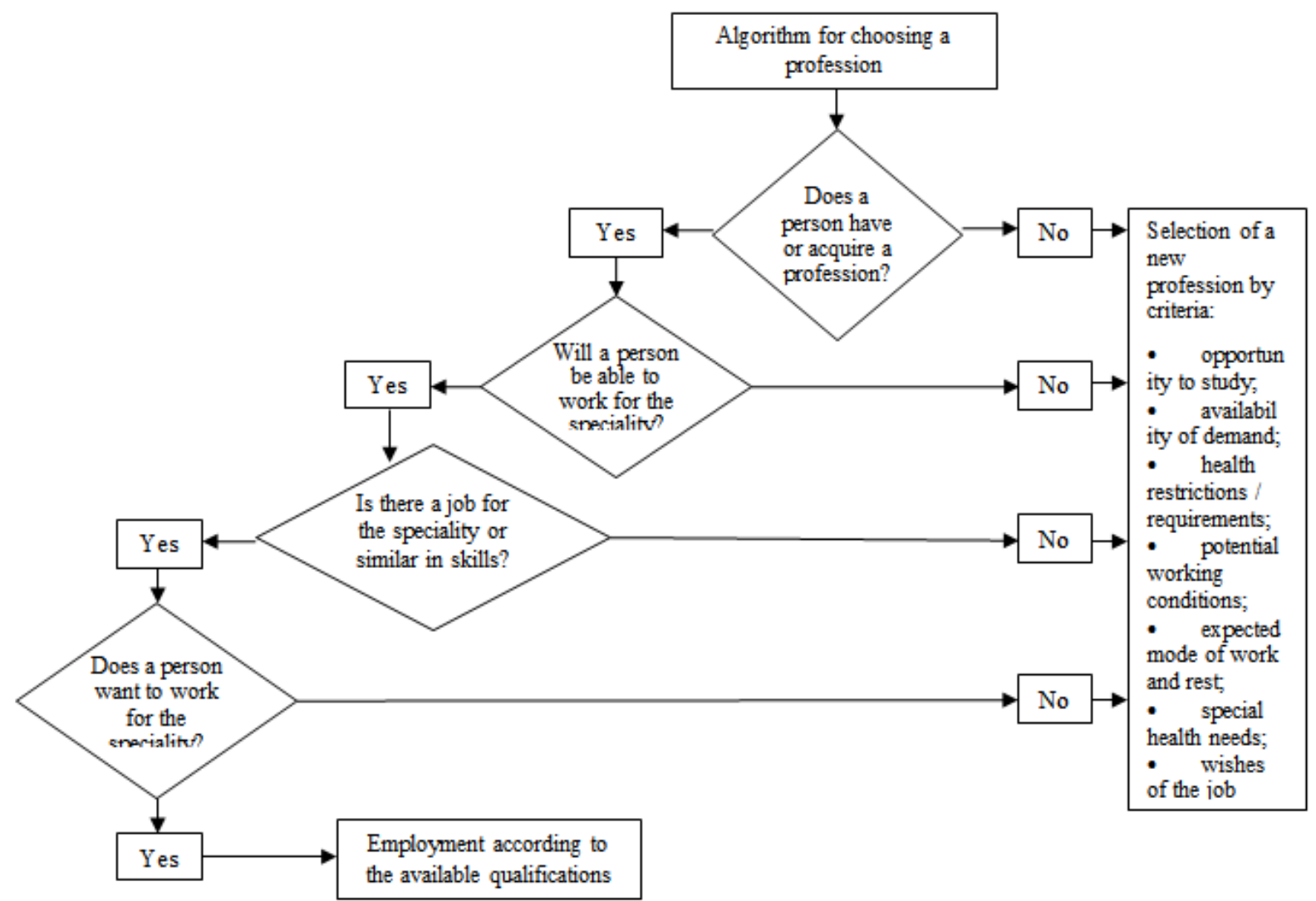

Figure 1. Algorithm for choosing a profession for a person with a disability

Thus, if a person worked before obtaining the status of a person with a disability, first of all, MSEC examines the ability of this person to work in his speciality. Similarly, if a person was in the process of receiving an education, in that case, an examination of the possibility of continuing this education and further work in this speciality is determined. A list of other occupations that a person with a disability could potentially work in may also be indicated.

A person with a disability may be trained or have a profession acquired before becoming disabled. In this case, the diagnosis of the health of a person with a disability, the ability to partial or complete rehabilitation is conducted. So, IRP provides information on the degree of suitability of a person with a disability to the profession: in full, with a limit on the amount of work performed and determining the length of the working day.

If a person with a disability can work according to a previously obtained qualification or a profession where once acquired knowledge and skills can be applied, a labour market analysis is performed. If there is a suitable vacancy, a person with a disability may be offered a job. At the same time, one of the essential selection criteria is the own desire of a person with a disability to work at a specific job.

In this case, as in the case of lack of work in the speciality or absence of any qualifications, such person may be offered training or retraining in another thing. In turn, the choice of the study's direction begins with vocational guidance and reorientation (Organization and management of the system of professional rehabilitation of the disabled, 2002). Most people with disabilities face difficulties in choosing a profession (speciality) that would meet two criteria at the same time:

1) was acceptable to them following the state of health, personal abilities, capabilities, individual psychological qualities;

2) it was in demand in the labour market.

The system of vocational guidance is designed to help people with disabilities in the right choice of profession, which would simultaneously meet these two criteria mentioned above.

Indeed, one of the ways to solve the problem of employment of people with disabilities is to improve and promote vocational training for this group of population. For achieving this goal in Ukraine, there are several regulations, the implementation of the provisions of which are engaged in both governmental and non-governmental institutions, organizations and enterprises. Moreover, in the course of reforms in the social and educational spheres, the state has recently taken steps to improve the quality of life of persons with disabilities by promoting their physical, social and occupational rehabilitation.

The Law of Ukraine "About Professional (Vocational) Education" regulates the rights of persons with disabilities to have the possibility to get the professional (vocational) 
education (Verkhovna Rada, 1998). Persons with disabilities are included in the list of persons entitled to a special social status in the field of professional (vocational) education (Verkhovna Rada, 1998). Also, art. 42 defines state guarantees for persons with disabilities in the field of professional and vocational and technical education, including the fact that other things being equal, persons with disabilities and persons with special educational needs have a priority right to enroll at institutions of professional (vocational) education (Verkhovna Rada, 1998).

Analyzing the legal acts, we can conclude that the legislative acts do not explicitly name the criteria by which the choice of vocational training for persons with disabilities is realized; however, some requirements are still followed. According to the resolution of the Cabinet of Ministers of Ukraine "On approval of the Procedure for vocational training, retraining and retraining of the disabled at the expense of the Fund for Social Protection of the Disabled" from 27.12.2006 No.1836 vocational training of persons with disabilities may be carried out in the following (The Cabinet of Ministers of Ukraine, 2006):

- the inability to find a job due to lack of the necessary qualifications;

- the need to change qualifications due to lack of work, which corresponds to the professional skills of a person with a disability;

- loss of ability to perform work in the previous profession;

- lack of profession;

- the need to select a job for a person with a disability, including the condition of work at home, following the recommendations of MSEC, available qualifications and taking into account the personal wishes of this person.

Vocational training of persons with disabilities is carried out taking into account the recommendations of MSEC, individual rehabilitation programme, the requirements of state educational standards, other regulations on vocational, higher education and social protection of persons with disabilities. Given the above, we can conclude that following the above resolution of the Cabinet of Ministers of Ukraine No.1836 criteria that allow you to choose the direction of vocational training of persons with disabilities; there are several factors listed above.

According to the Regulation on the Procedure for providing the Fund of Compulsory State Social Insurance of Ukraine in case of unemployment services for vocational training, retraining or advanced training, approved by a joint order of the Ministry of Labour and Social Policy of Ukraine and the Ministry of Education and Science of Ukraine № 53/59 of 13.02. 2001 (with changes made following the orders of the Ministry of Labour and Social Policy № 414/482 of 28.08.2002, №
$89 / 314$ of 19.04 .2004 , № 374/691 of 10.10.2006) vocational training of persons with disabilities registered with the State employment service, organized by it in coordination with the Department of Labour and Social Protection following the needs of the labour market (Ministry of Health of Ukraine, 2007).

However, this is a legislative approach. Also, there are several impressive lists of criteria set out in the Handbook, prepared in the framework of the UNDP Project, the International Labour Organization and the State Employment Centre "Social integration of people with disabilities through access to employment"(Semyhina, Ivanova, 2010). According to this Handbook, selection criteria for people with disabilities have been established. In our opinion, these criteria can be the basis for the criteria for selecting areas of training for people with disabilities, which are:

- education;

- professional qualification, work experience (including before and after disability);

- nature of disability (congenital, acquired, an accident at work, etc.);

- recommendations contained in the individual rehabilitation programme for professional and occupational rehabilitation of the person;

- expectations from the future workplace regarding working conditions, working hours, rest, etc.;

- features of the applicant's state of health that prevent him from working, and possible ways to overcome them;

- working conditions which are unsuitable for the applicant, and known to the applicant ways to neutralize them;

- special needs related to health, in particular with overcoming disabilities (for example, the need to equip the premises with ramps, the frequency and duration of breaks in work, the period of working hours, etc.);

- wishes and possible restrictions of the applicant regarding the location of the workplace in terms of transport accessibility, etc.

Following the National Report "Labour and Employment of Persons with Disabilities in Ukraine", prepared for implementation by the Decree of the President of Ukraine dated 18.12.2007 №1228/2007 “On Additional Urgent Measures to Create Favourable Living Conditions for Persons with Disabilities" and instructions of the Cabinet of Ministers of Ukraine from 24.06.2009 № 2700/3-09.

Occupational rehabilitation is a system of measures designed to take into account the aptitudes, physical, mental and psychological capabilities of the person and aimed at mastering the skills of employment and adaptation to working conditions, including by creating particular or specially adapted jobs (Verhovna Rada, 2005). 
Accordingly, the section of the IRP "Occupational Rehabilitation" should include a description of all factors and elements of future employment of a person with a disability. It must specify all the necessary working conditions, the necessary restrictions on the performance of certain functions and tasks, special requirements for labour protection, safety, etc., the need to use special equipment or extraordinary workplace, etc.

Employment of persons with disabilities takes into account:

- individual aptitudes and human abilities;

- MSEC recommendations;

- recommendations of employment service specialists;

- wishes of a person with a disability;

- the employer's possibility to adapt to the workplace if necessary, following the needs of a person with a disability.

According to the Handbook (Semyhina, Ivanova, 2010), when choosing a profession for a person with a disability, it is advisable to discuss with this person the main criteria for selecting a job, which are essential for this person not only from a medical point of view but also socially. Such factors or working conditions include, but are not limited to, such as shown in table 1 .

For example, a person with respiratory disease may be contraindicated to work in a room where there is a lot of dust. For people with disorders of the cardiovascular system, working conditions with intense vibration may be contraindicated.

However, narrowing the recommendations to only a few professions is not valid. Thus, careers that are different in name and content can usually have similar working conditions - for example, office professions. At the same time, the same job name may differ in working conditions at different enterprises. Certain professions, in essence, exclude the possibility of involving people with specific physical disabilities and diseases (Ministry of Health of Ukraine, 2007). For example, for work at height, a permanent hearing loss is contraindicated, for the result of a crane driver - diseases of the visual organs, for work on mechanical equipment (lathes, milling and other machines, stamping presses, etc.) limitation is a violation of the vestibular apparatus.

Table 1. Working conditions which are essential to consider when choosing a profession

\begin{tabular}{|c|c|}
\hline Group of factors & Individual factors \\
\hline Sanitary and hygienic & $\begin{array}{l}\text { work outdoors, indoors, in a domestic microclimate; } \\
\text { air: temperature, humidity, speed, air conditioning; } \\
\text { harmful working conditions: the presence of allergens, industrial dust, toxic substances, irritant } \\
\text { substances, } 46 \text { ionizing radiation, sources of infrared radiation, electromagnetic field, vibration; } \\
\text { lighting, noise. }\end{array}$ \\
\hline $\begin{array}{l}\text { An acceptable degree of nervous and } \\
\text { psychological stress }\end{array}$ & $\begin{array}{l}\text { complexity of actions, lack of time, responsibility and emotional load, decision-making in a limited } \\
\text { time, etc.; } \\
\text { performing simple or complex activities according to an individually designed plan. }\end{array}$ \\
\hline Acceptable physical activity & $\begin{array}{l}\text { maximum single weight of lifting cargo; } \\
\text { physical activity during the work shift; } \\
\text { the number of movements per hour. }\end{array}$ \\
\hline Intellectual load & $\begin{array}{l}\text { what part of the work is occupied by simple, standardized tasks, and which require memory load, } \\
\text { simultaneous use of such, for example, skills as several languages, creative tasks, tasks with a large } \\
\text { number of calculations that require constant concentration, use of data analysis, etc. }\end{array}$ \\
\hline Time for work and rest & $\begin{array}{l}\text { length of the working day, work in night shifts, in several changes; } \\
\text { requirements for standardization of the working day, working hours; } \\
\text { given the rhythm of the labour process (in particular, work on the production line); } \\
\text { breaks for food, medical procedures, taking medication, etc.; } \\
\text { business trips during the working day, business trips. }\end{array}$ \\
\hline $\begin{array}{l}\text { Specific and dangerous working } \\
\text { conditions }\end{array}$ & $\begin{array}{l}\text { work at height; } \\
\text { maintenance of moving mechanisms; } \\
\text { work among potential sources of increased injuries. }\end{array}$ \\
\hline Working posture & $\begin{array}{l}\text { free, forced, constant, comfortable position of the body and limbs; } \\
\text { work is associated with long walks; } \\
\text { admissible inclination of the case: angle, frequency; } \\
\text { sharp turns, tilts of the head. }\end{array}$ \\
\hline Psychophysiological factors & $\begin{array}{l}\text { accuracy of coordination of movements; } \\
\text { attention: long concentration, fast switching; } \\
\text { tension of sight, hearing, visual, auditory load; } \\
\text { duration of the speech and respiratory load. }\end{array}$ \\
\hline Form of labour organization & $\begin{array}{l}\text { individual, teamwork (without restrictions or with a favourable psychological climate); } \\
\text { homework. }\end{array}$ \\
\hline
\end{tabular}




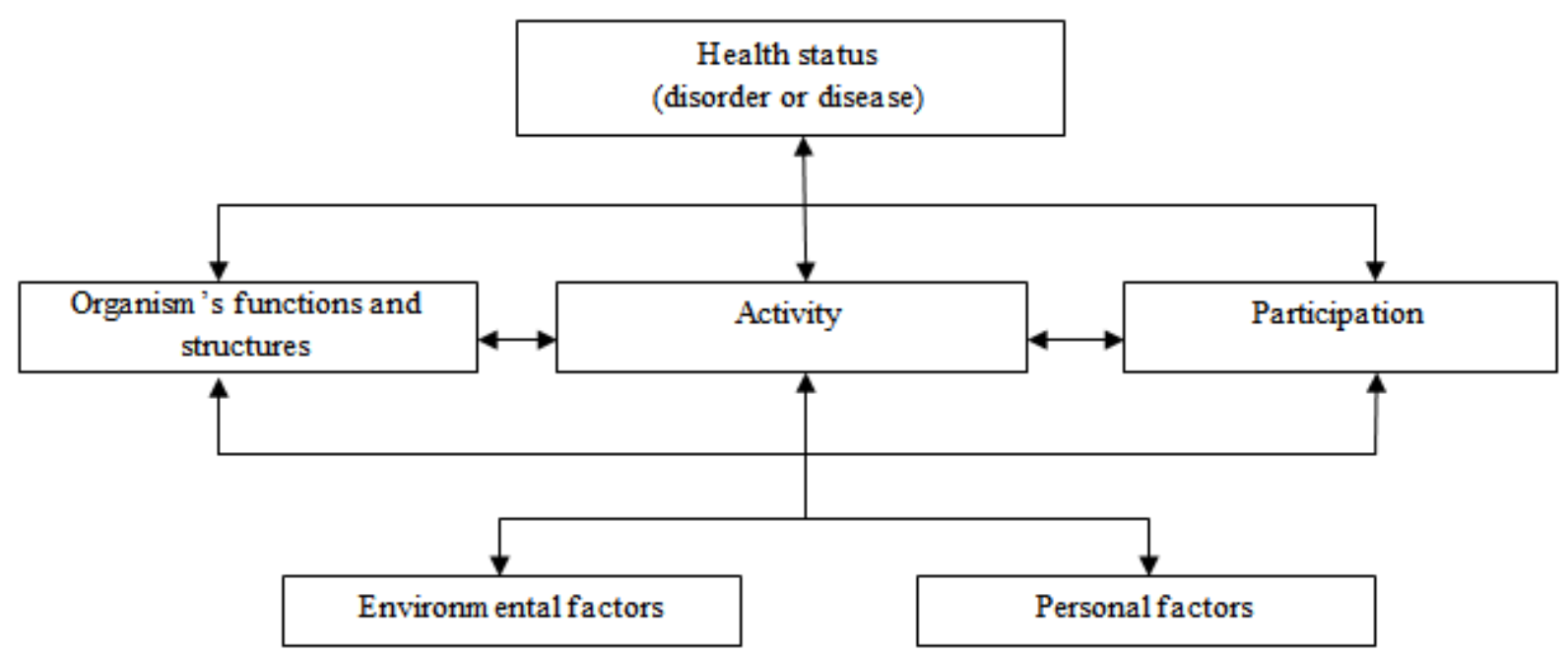

Figure 2. Interaction between the components of the ICF

The Procedure for conducting medical examinations of specific categories of workers contains a list of general medical contraindications to work with harmful and dangerous factors of the production environment and the labour process (Ministry of Health of Ukraine, 2007).

As noted in several analytical reports, the IRP often contains general information, which is not always sufficient to make the optimal decision. Therefore, it is advisable always to discuss the choice of profession with the person. Besides, the Ministry of Health is actively pursuing reforms aimed at, among other things, improving processes and improving the efficiency of employment of persons with disabilities.

Thus, at the end of 2017, the government approved an action plan for the implementation in Ukraine of the International Classification of Functioning, Restrictions on Life and Health and the International Classification of Functioning, Restriction of Life and Health of Children and Adolescents (Ministry of Health of Ukraine, 2018). This classification can be applied to anyone, not just people with disabilities.

When completing the Individual Rehabilitation Programme (IRP), MSEC will be guided by the International Classification of Functioning of Life and Health Restrictions (ICF), which provides a scientific basis for understanding and studying health and health-related conditions, defines a unified language and schemes for describing health conditions and offers definitions for health-related components such as education and employment. This classification allows you to compare data by countries and regions, simplifies the exchange of information and allows informatization and automation of processes. It should also be emphasized that the ICF has changed its approach and, instead of classifying health effects, has introduced a classification of "health components". ICF combines several components (Figure 2), which include: health, body functions and body structure, environmental factors and personal factors, activities and participation. And as the compilers of the ICF rightly point out, all these components are interconnected.

ICF defines the activity as "a person's performance of a task or action", and the participation as "involvement of a person in a life situation" (Davis, 2013).

Activities and participation include the following areas:

- Learning and application of knowledge.

- General tasks and requirements.

- Communication.

- Mobility.

- Self-service.

- Homelife.

- Interpersonal interactions and relationships.

- The main spheres of life.

- Community life, social and public life.

Health status and other related conditions are assessed on an individual basis in each of these areas. Activity and participation in these areas are evaluated by two qualifiers: productivity and ability. As explained in the ICF, productivity, in this case, describes what a person does in his or her current environment. In contrast, the ability qualifier describes a person's ability to perform a task or action and indicates the highest possible level of functioning that a person can achieve in this area at present (Davis, 2013). However, the presence of health disorders will not always lead to deterioration in productivity and ability. An example is an HIV-infected person who may have a productivity disorder due to stigma, but this person may not have limitations on ability. A person with mobility impairment may have ability limitations without assistance, as well as productivity constraints without special equipment and vehicles.

The ICF is based on medical and social models of disability. According to the medical model, disability is considered as a disease that requires medical treatment. 
Doctors are the primary professionals who are responsible for helping people with disabilities to fight their illness. In many countries around the world, this model is the most common or quite influential. In this model, a person with a disability receives the status of a patient with all the corresponding consequences: reduced expectations of others about the productivity of such a person at work formed an attitude as to the patient who cannot live a full social life and make a total contribution to the socio-economic development of their country.

At the same time, in recent decades, the social model of disability, whose supporters try to oppose the moral or karma model (whose supporters consider disability to be a punishment of higher powers or karma) and the medical model, has become increasingly popular in the developed world. According to the social model, society itself is responsible for observing people with disabilities as people with disabilities (The Cabinet of Ministers of Ukraine, 2018). "Disability is superimposed on our problems in the form of unjustified isolation and exclusion from public life. Thus, people with disabilities become a depressed group of the population". In this case, disability is defined as "lack or limitation of activity caused by the modern organization of society, which partially or completely does not take into account persons with physical pathologies, and thus, excludes them from major events and trends in public life" (The Cabinet of Ministers of Ukraine, 2018). The social model demonstrates that the problems of people with disabilities are the result of social oppression and exclusion.

The ICF combines both models to take into account all possible aspects of health and the various factors associated with this condition.

It is necessary to distinguish between the medical and social component and the transfer of social functions from physicians to specialists and experts on issues of social life and social policy. In Ukraine, the medical system is still used, while in developed countries, they are moving to social or a combination of medical and social models. The purpose of the concept of system reforming of medical and social expertise (The Cabinet of Ministers of Ukraine, 2018) is to improve the approach to the establishment of disability with the introduction of changes based on the principles of the ICF and the use of WHO information technology. Besides, the objectives of the concept include:

- introduction of a new system for Ukraine to assess the functioning and needs of social assistance based on the separation of medical and social functions of medical and social expert commissions;

- introduction of a system for assessing the functioning, vital functions and health of the ICF by primary care physicians, the inclusion of this service in the package of the List of medical services for the provision of primary health care; ensuring and establishing interdepartmental interaction in assessing the state of health, life and functioning of a person and between different parts of the rehabilitation process and the sequence of various forms and stages of rehabilitation, which, in turn, will create conditions for the maximum possible restoration of a full life;

- introduction of the use of ICF as a clinical tool for needs assessment, appropriateness of treatment methods to specific conditions, evaluation of professional suitability, rehabilitation and evaluation of results.

It is expected that the implementation of this Concept will allow, among other things, reduce the direct and indirect economic losses due to full or partial incapacity for work of persons with disabilities (The Cabinet of Ministers of Ukraine, 2018).

\section{Conclusions}

Thus, the selection of areas for retraining of a person with a disability takes place in several stages, in which the person with a disability, MSEC and the State Employment Service take part. To formulate recommendations, MSEC takes into account the types of restrictions on the life of a person with a disability, previous qualifications and work experience, the opportunity to work in a particular profession. In turn, the employment service, except the recommendations of MSEC, if there are some, also takes into account the demand for specific occupations and the possibility of retraining a person with a disability to obtain a new profession.

In the process of choosing a profession for a person with a disability, it is essential to take into account some factors: the possibility of studying in the desired speciality; availability of demand for certain types of professions; restrictions/requirements for candidates on health indicators; potential working conditions in the chosen thing; the expected mode of work and rest; special health-related needs that require adaptation of the workplace; wishes of the job applicant.

Thus, it is possible to conclude that the bases of the criteria for choosing the areas of training of persons with disabilities are the physical and psycho-emotional characteristics of a person with disabilities. When selecting a vocational training option for people with disabilities, there is a conflict between two paradigms. On the one hand, the supporters of economic efficiency will point to the main selection criterion - saving budget funds. At the same time, human rights activists will try to find a balance between expended resources and achieving equality between market participants labour, in particular, through the exercise of their rights and freedoms to choose a profession freely. 


\section{REFERENCES}

[1] Colella, A., \& Bruyère, S. (2011). Disability and employment. In S. Zedeck (Eds.), APA handbook of industrial and organizational psychology, 473-504. American Psychological Association, Washington, DC: US.

[2] Davis, L (2013). The Disability Studies Reader (4th ed.). http://ieas-szeged.hu/downtherabbithole/wp-content/uploa ds/2018/02/Lennard-J.-Davis-ed.-The-Disability-Studies-R eader-Routledge-2014.pdf\#page $=221$

[3] Gokcen, A. \& Gonca, B. (2017). Occupational Therapy Occupation Focused Holistic Practice in Rehabilitation. In A. Gokcen \& B. Gonca (Eds.), Community Participation in People with Disabilities. doi: 10.5772/intechopen. 68470

[4] Khayatzadeh-Mahani, A., Wittevrongel, K., Nicholas, D. \& Zwicker, JD. (2020). Prioritizing barriers and solutions to improve employment for persons with developmental disabilities, Disability and Rehabilitation, 42(19), 2696-2706. doi:10.1080/09638288.2019.1570356

[5] Ministry of Health of Ukraine. (2007). About the statement of forms of the rehabilitation individual programme of the disabled person, the disabled child and the Order of their drawing https://zakon.rada.gov.ua/laws/show/z1197-07\#Text

[6] Ministry of Health of Ukraine. (2007). On the statement of the Procedure for carrying out medical examinations of workers of certain categories. https://zakon.rada.gov.ua/ laws/show/z0846-07\#Text

[7] Ministry of Health of Ukraine. (2007). On approval of the individual programme of rehabilitation of invalids, disabled children and their preparation Procedure. https://zakon.rada.gov.ua/laws/show/z1197-07

[8] Ministry of Health of Ukraine. (2018). Action plan for the implementation of the International Classification of Functioning (updated) https://www.kmu.gov.ua/news/uryad-zatverdiv-plan-zahod iv-z-vprovadzhennya-mizhnarodnoyi-klasifikaciyi-funkcio nuvannya

[9] Miroshnychenko, O., Pasichnyk, I., Voznyuk, A., Kubitskyi, S., Roganova, M., Tsvietkova, H., Shorobura, I., Bloshchynskyi, I. (2020). Study of Ukrainian Polar Explorers' Psychological Readiness for Extreme Environments at the Antarctic Station. International Journal of Human Movement and Sports Sciences, 8(6), 455 - 461. DOI: $10.13189 /$ saj.2020.080618.
[10] Organization and management of the system of professional rehabilitation of the disabled. (2002) [Electronic resource]. https://helpiks.org/3-25085.html

[11] Semyhina, T., \& Ivanova, O. (2010). Job placement and employment of people with disabilities: a guide for employers.

https://www.dcz.gov.ua/sites/default/files/imce/oon.pdf

[12] The Cabinet of Ministers of Ukraine. (2006). The procedure for professional training, advanced training and retraining of disabled people registered with the State Employment Service, at the expense of the Fund for Social Protection of Disabled People. https://www.kmu.gov.ua/npas/61851560

[13] The Cabinet of Ministers of Ukraine. (2007). On approval of the Regulations on the individual rehabilitation programme for the disabled. https://zakon.rada.gov.ua/laws/show/757-2007-\%D0\%BF

[14] The Cabinet of Ministers of Ukraine. (2018). About the Concept of reforming the medical system and social examination.

https://moz.gov.ua/uploads/1/9149-pro_20181212_1_dod. pdf

[15] Truxillo, D. M., \& Fraccaroli, F. (2013). Research themes on age and work: Introduction to a Special Issue. European Journal of Work and Organizational Psychology, 22(3), 249-252. doi:10.1080/1359432X.2013.786604

[16] Verhovna Rada. (2005). Law of Ukraine about the rehabilitation of persons with disabilities in Ukraine. https://zakon.rada.gov.ua/laws/show/2961-15\#Text

[17] Verkhovna Rada. (1998). Law of Ukraine about professional (vocational) education. https://zakon.rada.gov.ua/laws/show/103/98-\%D0\%B2\%D $1 \% 80 \#$ Text

[18] Vornholt, K., Villotti, P., Muschalla, B., Bauer, J., Colella, A., Zijlstra, F., Van Ruitenbeek, G. Uitdewilligen, S., \& Corbière, M. (2018). Disability and employment - overview and highlights. European Journal of Work and Organizational Psychology, 27(1), 40-55. doi:10.1080/1359432X.2017.1387536

[19] Rucska, A., Perge, A. (2020). Narratives of Adoption. Universal Journal of Public Health, 8(4), 141 - 147. DOI: 10.13189/ujph.2020.080405

[20] Kateta, E., Villiers, J., Iita H. (2020). Knowledge, Attitudes and Practices of Patients Diagnosed with Tuberculosis Related to Tuberculosis Treatment Adherence in Keetmanshoop District, Namibia. Universal Journal of Public Health, 8(2), 43 - 56. DOI: 10.13189/ujph.2020.080201. 